\title{
PEMBELAJARAN MELALUI SENTRA SENI DALAM MENGEMBANGKAN KREATIFITAS ANAK USIA DINI
}

\author{
Hermansyah \\ Institut Agama Islam Yasni Bungo \\ Email: mpdihermansyah@gmail.com
}

\begin{abstract}
Most children are born smart. Thus, they are also equipped with creativity Education as a child will determine overall success in the future. In childhood it is the initial foundation to educate children. The purpose of this study was to find: (1) learning planning done by teachers or parents in establishing children's creativity through learning centers of art. (2) the implementation and efforts of the teacher or parent in the learning of art centers that are carried out by teachers or parents in the development of children's creativity, and (3) evaluation of the development of creativity in teachers or parents in the arts. This study uses a qualitative approach, data collection with interview observation techniques and documentation of the determination of research subjects is done by using purposive sampling.
\end{abstract}

Keywords: Learning, Art Centers, Early Childhood Creativity.

\begin{abstract}
Abstrak
Sebagian besar anak dilahirkan cerdas. Dengan demikian, mereka juga dibekali kreativitas Pendidikan masa kanak-kanak sangat menentukan keberhasilan secara keseluruhan dimasa mendatang, Pada masa kanak-kanak inilah sebagai fondasi awal mendidik anak. Tujuan penelitian ini untuk menemukan: (1) perencanaan pembelajaran yang di lakukan oleh guru ataupun orang tua dalam penegem kreativitas anak melalui pembelajaran sentra seni. (2) pelaksanaan serta upaya yang di lakukan guru ataupun orang tua pada pemebelajaran sentara seni yang di lakukan guru ataupun orang tua dalam pengembangan kreativitas anak, dan (3) evaluasi pengembangan kreativitas yang di lakukan guru ataupun orang tua sentara seni. Penelitian ini menggunakan pendekatan kualitatif, pengumumpulan data dengan tehnis observasi wawancara dan dokumentasi penentuan subjek penelitian di lakukan dengan mengunakan purposive sampeling.
\end{abstract}

Kata Kunci: Pembelajaran, Sentra Seni, Kreatifitas Anak Usia Dini.

Nur El-Islam, Volume 6, Nomor 1, April 2019 


\section{A. PENDAHULUAN}

\section{Latar Belakang}

Sebagian besar anak dilahirkan cerdas, mereka juga dibekali kreativitas. ${ }^{1}$ Pendidikan masa kanak-kanak sangat menentukan keberhasilan secara keseluruhan dimasa mendatang. Pada masa kanak-kanak inilah sebagai pondasi awal mendidik anak. Hal ini dikarenakan fitrah anak masih terjaga, artinya alam memberikan kepada setiap anak perangkat untuk mengarungi kehidupan dengan bekal itu. Bekal alam memberikan kecukupan bagi manusia untuk mencapai kecakapan hidup. Pendidikan pada hakikatnya, memiliki tujuan yang hakiki yakni humanisasi. Pendidikan memiliki makna dasar memanusiakan manusia. Membuat manusia kembali pada fitrahnya sebagaimana yang telah dijelaskan Allah dalam al-qur'an surat Ar-rum ayat 30 yang berbunyi:

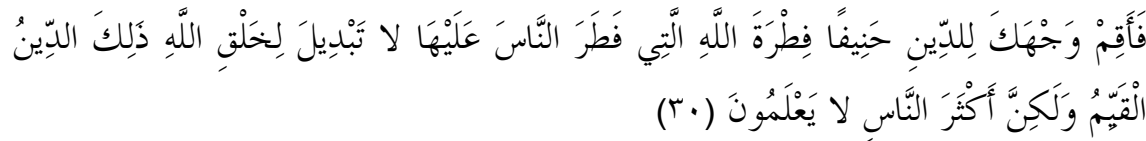

“Maka hadapkanlah wajahmu dengan Lurus kepada agama Allah; (tetaplah atas) fitrah Allah yang telah menciptakan manusia menurut fitrah itu. tidak ada peubahan pada fitrah Allah. (Itulah) agama yang lurus; tetapi kebanyakan manusia tidak mengetahui." (Q.S.Ar-rum/30:30). ${ }^{2}$

Kemudian, Nabi Muhammad SAW bersabda:

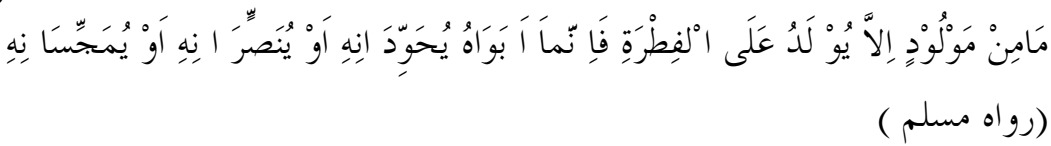

“Tidak ada dari seorang anak (adam) melainkan dilahirkan atas fitrah (Islam), maka kedua orang tuanyalah yang menjadikannya

${ }^{1}$ Departemen Pendidikan Nasional Direktorat Jenderal Pendidikan Tinggi Direktorat Pembinaan Pendidikan Tenaga Kependidikan Dan Ketenagaan Perguruan Tinggi, Pembembangan Kreativitas Anak Usia Dini, Jakarta 2005, h. 88.

${ }^{2}$ Depag RI. 2004, Al-qur'an dan terjemahannya.(Proyek Pengadaan Kitab Suci Alqur'an, Jakarta), h. 245. 
beragama Yahudi atau beragama Nasrani atau beragama Majusi.” (HR. Muttafaq 'Alaih). ${ }^{3}$

Salah satunya adalah dengan mengembalikan manusia menjadi cerdas dan kreatif guna menjangkau perkembangan hidupan. Pendidikan berupaya mendorong anak didik berani menghadapi problematika kehidupan. Pendidikan Anak Usia Dini (PAUD) menjadi sedemikian penting, karena pendidikan manusia pada lima tahun pertama sangat menentukan kualitas hidup selanjutnya. ${ }^{4}$ Melihat demikian penting tugas guru ataupun orang tua PAUD, maka sudah seharusnya setiap guru ataupun orang tua menyadari atau disadarkan akan tugas utamanya mendidik dan mengasuh anak usia dini. Sangat perlu guru ataupun orang tua membekali dan dibekali kecakapan sebagai pendidik. ${ }^{5}$ Dengan demikian, guru ataupun orang tua dapat melaksanakan tugas dan fungsinya dengan baik, optimal dan maksimal.

Bermain memberikan kesempatan pada anak untuk mengekspresikan dorongan-dorongan kreatifnya sebagai kesempatan untuk merasakan obyek-obyek dan tantangan untuk menemukan sesuatu dengan cara-cara baru, untuk menemukan penggunaan suatu hal secara berbeda, menemukan hubungan yang baru antara sesuatu dengan sesuatu yang lain serta mengartikannya dalam banyak alternatif cara. Selain itu bermain memberikan kesempatan pada individu untuk berpikir dan bertindak imajinatif, serta penuh daya khayal yang erat hubungannya dengan perkembangan kreativitas anak. ${ }^{6}$

Kreativitas dan bakat pada diri anak perlu dipupuk dan dikembangkan. Dengan kreativitas dan bakat yang dimilikinya itu

${ }^{3}$ Abdul Majid Khon, Hadis Tarbawi, (Jakarta: Kencana Prenada Media Group, 2012), h. 235.

${ }^{4}$ Imas Kurniasih Pendidikan Anak Usia Dini. (Jakarta: Edukasia, 2009), h. 90.

${ }^{5}$ Yuliani S Nuraini, Konsep Dasar Pendidikan Anak Usia Dini, (Jakarta: PT Indeks, 2009), h. 102.

${ }^{6}$ Luluk Asmawati, dkkk Pengelolaan Kegiatan Pengembangan Anak Usia Dini (Jakarta: Universitas Terbuka Kementrian Pendidikan Nasional, 2010), h. 10-15. 
mereka dapat menjadi pribadi-pribadi yang kreatif. Sebagai pribadi yang kreatif, kelak mereka bukan saja dapat meningkatkan kualitas pribadinya,tetapi juga dapat meningkatkan kualitas kehidupan bangsa dan negara. Perilaku kreatif adalah hasil pemikiran kreatif. Hendaknya sistem pendidikan dapat merangsang pemikiran, sikap, dan perilaku kreatif-produktif, di samping pemikiran logis dan penalaran. Namun dalam kenyataannya masih sedikit sekolah yang menyelenggarakan upaya pengembangan kreativitas dan bakat anak. Hal ini disebabkan antara lain oleh masih sangat langkanya literature yang membahas secara menyeluruh dan terinci mengenai kreativitas, bakat, dan upaya-upaya pengembangannya. ${ }^{7}$

Pendidkan anak usia dini (PAUD) adalah salah satu bentuk pendidikan anak usia dini pada jalur formal yang sangat membantu bagi orang tua dalam meningkatkan perkembangan kreativitas dan kecerdasan anak. Teori Gallagher dalam munandar menyatakan bahwa kreativitas berhubungan dengan kemampuan untuk menciptakan sesuatu yang baru, yang belum ada sebelumnya. Bermain memberikan kesempatan pada anak untuk mengembangkan kreativitasannya. Ia dapat bereksperimen dengan gagasan-gagasan barunya baik yang menggunakan alat bermain atau tidak. Sekali anak merasa mampu menciptakan sesuatu yang baru dan unik, ia akan melakukan kembali pada situasi yang lain. Kreativitas memberi anak kesenangan dan kepuasan pribadi yang sangat besar dan penghargaan yang memiliki pengaruh nyata pada perkembangan pribadinya. ${ }^{8}$ Being creative is also important for young children, because it adds spice to the game. If creativity can make the game fun, they will feel happy and satisfied. ${ }^{9}$

Adapun indikator perkembangan anak di sentra seni dalam mengembangkan kreativitas anak usia dini adalah: anak mampu membuat kreasi berbagai bentuk dengan menggunakan tangan

${ }^{7}$ Martini Jamaris, Perkembangan dan Pengembangan Anak Usia Taman KanakKanak,(Jakarta, Remaja Rosdakarya, 2006), h.141.

${ }^{8}$ Noorlaila Iva. Panduan Lengkap Mengajar PAUD, (Jogjakarta: Pinus Book Publisher, 2010), h.112.

${ }^{9}$ Armstrong Thomas, On Their On Way Discovering And Encouraging Your Child Multiple Intelligence. (America: Educational Leadership, 2004), h. 69. 
ciptaan Allah dengan teknik merobek, meremas, menjiplak, menggunting, menempel, menganyam, melipat, mencocok, meronce dengan berbagai media, dan menggulung. Kreativitas pada anak taman kanak-kanak ditampilkan dalam berbagai bentuk, baik dalam membuat gambar yang disukainya maupun dalam bercerita atau dalam bermain seni di sentra seni. Salah satu kendala dalam mengembangkan kreativitas adalah sikap orang tua atau guru ataupun orang tua yang kurang memberi kesempatan perkembangan kreativitas secara optimal. Hal ini disebabkan oleh pandanganpandangan yang sempit, dalam arti bahwa anak harus menurut apa yang dikatakan oleh orang tua atau guru ataupun orang tua.$^{10}$

Berdasarkan hasil observasi, fakta yang ada di PAUD Diniyyah Bungo adalah pada beberapa tema pelaksanaan pembelajaran sentra seni dalam mengembangkan kreativitas anak adalah masih terdapat beberapa anak yang belum mampu berkreasi dan membuat karya padahal sebelumnya guru ataupun orang tua telah memberikan dorongan dan bimbingan dalam pelaksanaan pembelajaran sentra seni hal ini terjadi pada pelaksanaan pembelajaran mengisi pola pada gambar. Masih terdapat beberapa orang tua yang kurang berkenan dengan pelaksanaan pembelajaran sentra seni, orang tua menganggap anak tidak perlu diajarkan berbagai macam karya seperti melipat, menggambar, menggunting dan meronce. Orang tua hanya ingin anaknya diajarkan membaca, menulis dan berhitung dengan alasan untuk persiapan anak dalam memasuki sekolah dasar. Dengan demikian guru ataupun orang tua harus tetap mempunyai inisiatif agar pelaksanaan pembelajaran sentra seni dalam mengembangkan kreativitas anak terlaksana sesuai rencana dan tujuan yang diharapkan. ${ }^{11}$

Dalam mengembangkan kreativitas anak, diperlukan suatu pembelajaran kegiatan belajar yang sesuai yaitu dapat menggerakkan anak untuk meningkaan motivasi rasa ingin tahu dan

${ }^{10}$ Neni Arriyani. Panduan Pendidikan Sentra Untuk PAUD, (Jakarta: Sekolah AlFalah, 2006), h. 78.

${ }^{11}$ Hasil Observasi awal, Tanggal 12 Desember 2013. 
mengembangkan imajinasi yang mampu mendorong untuk mencari dan menemukan jawabannya, membuat pertanyaan yang membantu memecahkan, memikirkan kembali, membangun kembali, dan menemukan hubungan-hubungan baru. Kegiatan belajar yang sesuai, yaitu pengembangan kreativitas anak dengan menggunakan sumber belajar yang dapat digunakan untuk merealisasikan kegiatan-kegaitan yang kreatif. ${ }^{12}$

Pembelajaran diharapkan, agar pendidik memberikan perhatian dan kasih sayang dalam setiap tahapan perkembangan anak, agar anak merasa nyaman dan penuh kasih sayang. Kegiatan Pembelajaran Anak harus berpusat kepada anak. Kurikulum pedoman pengembangan program pembelajaran, merupakan salah satu bentuk pendidikan formal yang sesuai dengan UU No. 20 Tahun 2003 Pasal 1 ayat 14 menyatakan bahwa Pendidikan Anak Usia Dini (PAUD) adalah salah satu upaya pembinaan yang ditujukan pada anak sejak lahir sampai dengan usia 6 tahun yang dilakukan melalui pemberian rangsangan pendidikan untuk membantu pertumbuhan dan perkembangan jasmani dan rohani agar anak memiliki kesiapan dalam memasuki pendidikan yang lebih lanjut. ${ }^{13}$ Pembelajaran adalah suatu sistem yang bertujuan untuk membantu proses belajar siswa, yang berisi serangkaian peristiwa yang dirancang, disusun sedemikian rupa untuk mempengaruhi dan mendukung terjadinya proses belajar siswa yang bersifat internal. ${ }^{14}$

Pembelajaran adalah suatu kegiatan yang dilakukan secara sadar dan sengaja. Tujuan pembelajaran adalah perubahan prilaku dan tingkah laku yang positif dari peserta didik setelah mengikuti kegiatan belajar mengajar, seperti: perubahan yang secara psikologis akan tampil dalam tingkah laku (over behaviour) yang dapat diamati melalui alat indera oleh orang lain baik tutur katanya, motorik dan gaya

${ }^{12}$ Tesis Eli Harnida. Model Pembelajaran Beyond Center And Circle Time(BCCT) Pada Taman Kanak-Kanak Untuk Mengembangkan Kreativitas Anak, (Pustaka Program Pasca Sarjana IAIN sts Jambi), h. 9.

${ }^{13}$ Luluk Asmawati dkk. Pengelolaan Kegiatan Pengembangan Anak Usia Dini, (Jakarta: Universitas Terbuka, 2010), h. 88.

${ }^{14}$ B Uno Hamzah. Perencanaan Pembelajaran.(Jakarta: Bumi Aksara, 2011), h. 90. 
hidupnya. Hal ini dapat disimpulkan bahwa proses pembelajaran merupakan proses melibatkan guru ataupun orang tua dengan semua komponen tujuan, bahan, metode dan alat serta penilaian. Jadi proses pembelajaran merupakan suatu sistem yang saling terkait antar komponennya di dalam mencapai suatu tujuan yang telah ditetapkan. ${ }^{15}$

Pembelajaran berbasis sentra merupakan pembelajaran yang paling mutakhir yang dilaksanakan di lingkungan pendidikan anak usia dini; dengan karakteristik utamanya memberika pijakan (scaffolding) untuk membangun konsep aturan, ide, dan pengetahuan anak serta konsep densitas dan intensitas bermain. model pembelajaran sentra merupakan model pembelajaran yang menitik beratkan sentra bermain pada saat pembelajaran. Sentra bermain merupakan area kegiatan yang dirancang di dalam atau di luar kelas, berisi berbagai kegiatan bermain dengan bahan-bahan yang dibutuhkan dan disusun berdasarkan kemampuan anak serta sesuai dengan tema yang dikembangkan dan dirancang terlebih dahulu. Sentra memungkinkan anak untuk melakukan manipulasi terhadap berbagi obyek, terlibat dalam role playing saling bercakap-cakap dengan teman-temannya, bereksplorasi, berinteraksi secara fisik, emosional, sosial dan secara kognitif serta kegiatan variatif yang menarik lainnya.

Sentra memberikan kesempatan pada anak untuk bermain baik secara individual, kelompok kecil maupun kelompok besar dan bahkan secara klasikal. Anak diperbolehkan memilih kegiatan yang menarik baginya dan akhirnya akan menjadikan anak sebagai pembelajar yang aktif dan interaktif. Kegiatan bermain dilakukan anak dalam kelompok kecil di sentra atau area yang di dalamnya terdapat berbagai material bermain. Setiap sentra bermain telah disiapkan oleh guru ataupun orang tua sesuai dengan program pengembangan yang akan diajarkan kepada anak dengan jadwal yang telah ditentukan. Semua kegiatan bermain diarahkan untuk mencapai target yang disesuaikan dengan

${ }^{15}$ Koni Satria dan Hamzah B Uno. Assesment Pembelajaran, (Jakarta: Bumi Aksara, 2012), h. 78. 
kemampuan dengan minat anak (child oriented). Dengan menggunakan sentra bermain aktif, anak akan terlibat secara aktif baik secara fisik maupun mental karena akan mendapatkan berbagai pengalaman belajar dengan melihat, mendengar dan mengerjakan secara langsung atau praktek langsung (learning by doing). Model sentra menggunakan 3 jenis main, yaitu: Main Sensorimotor, anak main dengan benda untuk membangun persepsi. Main Peran, anak bermain dengan benda untuk membantu menghadirkan konsep yang sudah dimilikinya. Main Pembangunan, anak bermain dengan benda untuk mewujudkan ide/gagasan yang dibangun dalam pikirannya menjadi suatu bentuk nyata. ${ }^{16}$

Sentra seni atau pusat kegiatan seni merupakan tempat untuk menumbuh kembangkan kreativitas, imajinasi, inisiatif, dan rasa keindahan anak. Sentra seni harus membawa suasana yang riang gembira anak akan dapat berkreasi dan mengekspresikan diri sebebasbebasnya. Agar hal ini terjadi anak harus diberi kesempatan dan kebebasan melakukan kegiatan-kegiatan yang menurut mereka ingin melakukan kegiatan-kegiatan yang menurut mereka lakukan. Peran pendidik dalam hal ini hanya mengarahkan saja agar apa yang di lakukan anak benar-benar terarah dan dapat mencapai tahapan tertentu dalam perkembangannya. ${ }^{17}$ Sentra seni memiliki fokus memberikan kesempatan pada anak untuk mengembangkan berbagai keterampilannya terutama keterampilan tangan dengan menggunakan berbagai bahan dan alat, seperti: melipat, menggunting, mewarnai, membuat prakarya, melukis dan membuat prakarya dengan menggunakan adonan. Di sentra ini, anak bermain sambil belajar mengasah rasa keindahan, membangun kemandirian, kerja sama, tanggung jawab, bersosialisasi, melatih koordinasi mata, tangan, kaki dan pikiran.

Sentra seni adalah sentra yang kegiatannya terdiri dari keterampilan tangan seperti: melipat, menggunting, merekat,

${ }^{16}$ Suyadi. Permainan edukatif Yang Mencerdaskan: The Power of Smart Games For Children, (Yogyakarta: Power Books, 2009), h. 200.

${ }^{17}$ Utami Munandar. Pengembangan Kreativitas Anak Berbakat, (Jakarta: PT Indeks,2009), h. 66. 
prakarya, melukis, dan pertukangan. Sentra ini dimaksudkan untuk mengembangkan keterampilan dan kreativitas anak. Kegiatan di sentra seni meliputi 3M (melipat, menggunting, merekat), bekerja dengan bahan sisa, merobek, mencap, membentuk dengan bermacammacam alat, memercik, membuat cermin, bermain dengan cat minyak, stensil dan menetes dengan lilin kemampuan ini merupakan perkembangan motorik halus. Alat permainan yang digunakan adalah kertas gambar, piring kue, kancing baju, gunting, lem, benang woll, kertas/ wall paper, karton, manila, sendok es cream, spidol, crayon dan berbagai bahan sisa/ bekas. Melalui bahan-bahan baru dan pengalaman fisik secara langsung, sentra seni dapat menimbulkan rasa senang, mengembangkan dan mengeksplorasi daya kreativitas anak memacu komunikasi verbal dan non verbal, kepercayaan diri, perkembangan motorik halus dan kasar serta kemampuan intelektual anak. Bahan-bahan yang digunakan antara lain; kertas, cat air, krayon, spidol, gunting, kapur, lilin, kain, potongan bahan/gambar untuk digunting dan ditempel dan bahan-bahan seni lainnya. Bahan alami juga dapat digunakan seperti kayu, daun-daun, pasir, batu, kulit telur dan lain-lain. ${ }^{18}$

Kegiatan sentra seni merupakan hal yang sangat penting bagi pengembangan keterampilan seni anak. kegiatan seni juga memberi sumbangan pada pengembangan aspek-aspek perkembangan anak lainnya. Melalui kegiatan seni di sentra seni anak dengan bebas mengekspresikan imajinasinya dan menceritakan kepada guru ataupun orang tua apa yang telah di kerjakannya. Ruang, bahanbahan, dan peralatan yang di butuhkan anak hendaknya dapat dipenuhi dalam melakukan kegiatan seni agar anakdapat dengan bebas berkreasi dan berinisiatif membuat suatu karya seni. Pembuatan karya seni juga mempunyai tahap-tahap perkembangan yang dapat digunakan oleh guru ataupun orang tua atau pendidik anak usia dini untuk menilai sejauh mana tingkat perkembangan anak dan bagaimana mendorong anak mencapai tahapan yang lebih tinggi.

${ }^{18}$ Luluk Asmawati, dkk. Pengelolaan Kegiatan Pengembangan Anak Usia Dini, (Jakarta: Universitas Terbuka, 2010), h. 11.13. 


\section{Indentifikasi masalah}

Adapun yang menjadi masalah dalam penelitian ini adalah

a. Anak selalu diberikan tugas oleh guru dan orang tua membaca, menulis, dan berhitung.

b. Sebagian guru belum mampu mengembangkan kegiatan pembelajaran pada aspek kreativitas anak.

c. Anak belum mampu mengekreasikan media untuk menciptakan bentuk atau karya yang baru.

d. Beberapa anak terlihat diam dan tidak mau mengikuti guru.

e. Pembelajaran berpusat pada guru dan orang tua sehingga menjadikan anak pasif dan kurang mandiri.

\section{Teori dan Kajian terdahulu}

a. Penelitian dilakukan oleh Istiana dan Dorlina (2014). Dilatarbelakangi oleh rendahnya perkembangan kreativitas anak terutama dalam hal permainan finger painting. disebabkan kurang adanya inovasi dalam pembelajaran yang di berikan oleh guru.

b. Penelitian dilakukan oleh Mulia, Putri tahun (2016). Permasalahan dalam penelitian ini adalah rendahnya kreativitas anak dalam menciptakan sesuatu. Teknik pengambilan sampel yang digunakan yaitu teknik purposive sampling. Teknik pengumpulan data menggunakan teknik observasi. Instrumen penelitian menggunakan lembar observasi berupa rubrik penilaian. Teknik analisis data menggunakan uji regresi linear sederhana. Hasil uji regresi linear sebesar p $0,000<(0,05)$ menunjukkan bahwa ada pengaruh penggunaan media balok terhadap kreativitas anak.

\section{Tujuan penenelitian}

Berdasarkan indentivikasi masalah di atas maka, maka tujuan dari peneltian ini adalah untuk:

a. Menganalisis perencanaan, pelaksanaan,evaluasi pembelajaran melaui sentra seni dalam penegmabangan kreativitas anak yang 
di terapkan pendidik pada anak usai 5-6 tahun di Pendidkan anak usia dini( PAUD Diniyah)

b. Menganalisis faktor-faktor penghambat dalam pembelajaran melaui sentra seni dalam pengemabangan kreativitas anak di di Pendidkan anak usia dini( PAUD Diniyah)

c. Menganalisis upaya yang di lakukan guru pada pemebelajaran melaui sentra seni dalam pengemabangan kreativitas di Pendidkan anak usia dini( PAUD Diniyah)

\section{Metodologi}

Sistem pendekatan Penelitian adalah seperangkat asumsi yang saling berkorelasi satu dengan yang lain mengenai fenomena alam semesta. Dan pada dasarnya ada 3 (tiga) pendekatan penelitian yang selama ini digunakan dalam penelitian ilmiah yaitu Penelitian Kualitatif, Penelitian Kuantitatif, dan Penelitian Triangulasi yang merupakan penggabungan dari Penelitian Kualitatif dan Penelitian Kuantitatif.

Penelitian kualitatif adalah tradisi tertentu dalam i1mu pengetahuansosial yang secara fundamental bergantung pada pengamatan pada manusiadalam kawasannya dan dalam peristilahannya. Penelitian kualitatif adalah riset yang bersifat deskriptif dan cenderung menggunakan analisis dengan pendekatan induktif. Proses dan makna (perspektif subyek) lebih ditonjolkan dalam penelitian kualitatif. Landasan teori dimanfaatkan sebagai pemandu agar fokus penelitian sesuai denganfakta di lapangan. Selain itu landasan teori juga bermanfaat untuk memberikan gambaran umum tentang latar penelitian dan sebagai bahan pembahasan hasil penelitian.

Terdapat perbedaan mendasar antara peran landasan teori dalam penelitian kuantitatif dengan penelitian kualitatif. Dalam penelitian kuantitatif, penelitian berangkat dari teori menuju data, dan berakhir pada penerimaan atau penolakan terhadap teori yang digunakan; sedangkan dalam penelitian kualitatif peneliti bertolak dari data, memanfaatan teori yang ada sebagai bahan penjelas, dan 
berakhir dengan suatu "teori". ${ }^{19}$ Penelitian ini merupakan sebuah studi yang akan menemukan dan menggali sejauh mana pembelajaran melalui sentra seni dalam mengembangkan kreativitas anak usia dini di PAUD diniyyah Bungo Provinsi Jambi. Pendekatan penelitian yang akan digunakan adalah aspek yang sangat penting dalam suatu penelitian, pendekatan penelitian yang sesuai dengan tujuan penelitian akan mendukung kemudahan bagi penelitian dalam menjalankan proses penelitian yang akan dijalankan. ${ }^{20}$

Dasar penelitian ini adalah kualitatif adalah menekankan pada orientasi teoritis, artinya lebih berorientasi untuk mengembangkan atau membangun teori-teori. Oleh karena itu penelitian deskriptif kualitatif lebih menggambarkan cara hidup subjek penelitian sesuai dengan persepsi, pemahaman dan interpretasi mereka sendiri sehingga penelitian deskriptif yaitu berupa kata-kata atau gambaran yang berasal dari data hasil wawancara, observasi dan dokumentasi.

Penelitian ini merupakan sebuah studi yang akan menemukan dan menggali sejauh mana pengembangan kreativitas anak melalui pembelajaran sentra seni. Pendekatan kualitatif digunakan untuk menguraikan, menggambarkan, menggali dan mendeskripsikan pembelajaran sentra seni tersebut sehingga nantinya akan mengembangkan kreativitas yang dimiliki anak. Sedangkan konsep yang digunakan dalam penelitian ini adalah konsep kreativitas anak usia dini.Pendekatan penelitian yang akan digunakan adalah aspek yang sangat penting dalam suatu penelitian, pendekatan penelitian yang sesuai dengan tujuan penelitian akan mendukung kemudahan bagi penelitian dalam menjalankan proses penelitian yang akan dijalankan. ${ }^{21}$

Secara umum, subjek penelitian ini mencakup seluruh karakteristik yang berhubungan dengan pembelajaran melalui sentra seni dalam mengembangkan kreativitasdi PAUD Diniyyah. Untuk memperoleh informasi tersebut, peneliti menggunakan teknik

\footnotetext{
${ }^{19}$ www.wikipedia.org/Penelitian kualitatif. Tanggal 15 Januari 2014.

${ }^{20}$ Iskandar. Metodologi Penelitian Pendidikan dan Sosial Kuantitaif dan Kualitatif, (Jakarta: Gaung Persada, 2008), h. 117.

${ }^{21}$ Ibid., h. 117.
} 
Purposive Sampling adalah teknik pengambilan sumber data dengan pertimbangan tertentu, orang yang dianggap paling tahu apa yang paling diharapkan sehingga akan memudahkan peneliti menjajahi objek yang akan diteliti. ${ }^{22}$

Subjek penelitian adalah pendidik, anak didik dan orang tua. mereka ini diamati dan diwawancarai secara langsung dengan tujuan untuk penyesuaian antara informasi yang diperoleh hasil observasi dengan melalui wawancara. Selain itu juga akan diperoleh informasi yang lebih lengkap.Penelitian ini bert ujuan untuk memecahkan berbagai permasalahan sehingga dibutuhkan data yang valid dan sesuai dengan objek penelitian.Data primer adalah data yang diambil langsung oleh peneliti kepada sumbernya, tanpa adanya perantara, Data primer ini diperoleh langsung dilapangan pada waktu penelitian. Dalam penelitian ada dua jenis data, yaitu data primer dan data sekunder.Data primer adalah data yang diambil langsung oleh peneliti kepada sumbernya, tanpa adanya perantara. Data primer ini diperoleh langsung di lapangan pada waktu penelitian sedang berlangsung yang berupa informasi tentang perkembangan metoda bermain sentra seni, kreativitas anak, APE yang digunakan wawancara dengan orang tua dan guru ataupun orang tua tentangpembelajaran melalui sentra seni dalam mengembangkan kreativitas anak. Data sekunder adalah data yang diambil secara tidak langsung dari sumbernya. Data sekunder dapat berupa dokumentasi tertulis yang terdapat di lapangan meliputi Rencana Kerja Harian dan Program Tahunan serta program pengembangan diri yang disusun oleh guru ataupun orang tua .

Adapun sumber data yang dipergunakan dalam penelitian ini terdiri dari:

a) Manusia, yaitu kepala sekolah, guru ataupun orang tua (wali kelas, guru ataupun orang tua sentra dan guru ataupun orang tua pengembangan diri) dan anak

b) Kondisi dan aktivitas pembelajaran di sekolah yaitu mencari tahu tentang proses pembelajaran yang dilaksanakan dalam mengembangkan kreativitas anak.

${ }^{22}$ Sugiyono. Memahami Penelitian Kualitatif, ( Bandung: Alfabeta, 2007), h. 54. 
c) Dokumen, yaitu berupa arsip, dokumen resmi, brosur, profil, jurnal, buku panduan, struktur organisasi dan lain-lain. Dengan adanya dokumen-dokumen tersebut diharapkan akan mendapatkan data yang berkaitan dengan program guru ataupun orang tua dalam upaya pelaksanaan pembelajaran melalui sentra seni dalam mengembangkan kreativitas anak.

\section{B. PEMBAHASAN}

1. Landasan Teori

a. Pembelajaran

Pembelajaran di pendidikan anak usia dini (PAUD) di harapkan agar pendidik memberikan perhatian dan kasih sayang dalam setiap tahapan perkembangan anak, kurikulum pedoman pengembngan program pemebelajaran di pendidikan anak usia diini merupakan salah satu bentuk pendidkan formal yang sesui dengan UU No.22 tahun 2003. Pasal 1 ayat 14 menyatakan bahwa pendidikan anak usia dini (PAUD)adalah salah satu upaya pemebinaan yang di tunjukan pada anak sejak lahir samapai dengan usia enam tahun yang di lakukan melaui pemberian ransangan pendidikan untuk membantu pertumbuhan dan perkemabngan jasmani dan rohani agar anak memiliki kesiapan dalam memasuki pendidikan yang lebih lanjut. ${ }^{23}$

Pembelajaran adalah suatu sistem yang bertujuan untuk membantu proses belajar siswa, yang berisi serangkaian peristiwa yang di rancang, disusu sediamikian rupa untuk mempengaruhi dan mendukung terjadinya proses belajar siswa yang bersifat internal. ${ }^{24}$ Agar anak merasa nyaman dan penuh kasih sayang. Kegitan pembelajaran anak usia dini melalui sentra seni ada 3 hal yang akan di lakukan guru ataupun orang tua di sentra seni PAUD Diniyyah yaitu: perencanaan, pelaksanaan, dan evaluasi. Tahap awal yang harus dikerjakan guru ataupun orang tua dalam pembelajaran sentra seni

${ }^{23}$ Luluk asnawati dkk. pengelolaan kegiatan perkembangan anak usia din, (Jakarta: Universitas Terbuka, 2010), h. 88.

${ }^{24}$ B Uno Hamzah. Perencanaan Pemebelajaran, (Jakarta: Bumi Aksara, 2011), h. 10. 
dalam pengembangan kreativitas anak usia dini adalah menyusun perencanaan karena perencanaan merupakan bagian dari tahap dalam rangka mewujudkan pelaksanaan kurikulum. Untuk itu harus disiapkan dan di rencanakan pembelajaran yang akan di laksanakan, seperti wawancara dengan Rosita berikut:

"Dalam pelaksanaan pembelajaran di sentra seni guru ataupun orang tua harus membuat perencanaan pembelajaran terlebih dahulu sebelum melaksanakan pembelajaran seperti perencanaan semester, perencanaan mingguan dan perencanaan harian.”25

Sebelum memulai pembelajaran sentra seni guru ataupun orang tua melakukan pijakan lingkungan main dan menata media pembelajaran dengan rapi sesuai dengan tema pembelajaran. Di dalam menyiapkan media pembelajaran guru ataupun orang tua melakukannya secara bersama-sama antar guru ataupun orang tua wali kelompok dan guru ataupun orang tua pendamping. Selanjutnya pelaksanaan yang di lakukan guru ataupun orang tua dalam mengelola sentra seni yaitu guru ataupun orang tua melakukan pijakan sebelum main kepada anak agar anak mengerti dan tertib pada saat main. Di dalam pelaksanaan pembelajaran guru ataupun orang tua mengatur posisi duduk anak sesuai dengan permainan yang dilakukan anak baik di kursi atau di lantai. Media yang dilakukan adalah disesuaikan dengan tema yang dilakukan/direncanakan. Kemudian guru ataupun orang tua menjelaskan dan menyampaikan materi pembelajaran dengan jelas kepada anak karena guru ataupun orang tua menguasai materi sesuai tema pembelajaran. Secara rinci akan penulis uraikan dari perencanaan, pelaksanaan, dan evaluasi pembelajaran sentra seni.

\section{b. Anak Usai Dini}

Menurut undang -undang No 20 tahun 2003 tentang sistem pendidikan nasional, anak usai dini adalah sekelompok manusai yang

${ }^{25}$ Wawancara RS 18 September 2014. 
berusia 0 sampai 6 tahun.berbeda dengan the national assocation for educational of young children (NAEYC) Memberikan batasan, anak usai awal (Earlychillhood) adalah anak yang sejak lahir samapai usia delapan tahaun. ${ }^{26}$ Usia dini merupakan usia yanng sangata menentukan dalam pembentukan karakter dan kepribadain seorang anak, pada masa ini anak terus menerus dalam ke adaan pertumbuhan dan perubahan sehinggga di butuhkan lingkungan yang dapat mendudkung pertumbuhan dan perkembangan yang optimal, ${ }^{27}$

\section{c. Sentra Seni}

Di dalam pembelajaran, guru ataupun orang tua harus dapat melakukan proses pengelolaan kelas sentra yang baik untuk dapat menciptakan proses pembelajaran yang efektif dan kondusif. Pengelolaan kelas yang baik akan melahirkan interaksi belajar mengajar yang baik pula. Tujuan pembelajaranpun akan dapt dicapai tanpa kendala yang berarti seorang guru ataupun orang tua harus memiliki kemampuan pengelolaan kelas yang baik. Tanpa kemampuan pengelolaan kelas yang baik, segala kemampuan guru ataupun orang tua yang lain dapat menjadi netral, dalam arti kurang memberikan pengaruh atau dampak kelas yang positif terhadap pembelajaran anak. model pembelajaran sekarang yang ada di dalam pendidikan anak usia dini adalah pembelajaran sentra. Seperti yang diketahui pembelajaran sentra adalah pembelajaran yang berpusat kepada anak.

Pembelajaran melalui sentra seni adalah sebagai bagian dari pembelajaran sentra atau BCCT dengan pembelajaran sentra seni diharapkan akan dapat mengembangakn imajinasi, kreativitas. Dalam mengembangkan imajinasinya anak dapat menggambar dan mewarnai sesuai dengan imajinasinya. Kemudian untuk mengembangkan kreativitas anak dalam sentra seni seperti dapat menciptakan hasil karya melalui berbagai kegiatan pembelajaran yang dilakukan. Dengan demikian seorang guru ataupun orang tua dan orang tua dapat

${ }^{26}$ Koni satria dan hamzah B Uno. Assesment Pembelajaran, (Jakarta: Bumi Akasara, 2012), h. 78.

${ }^{27}$ Dakdirotorium musfiroh. Cerdas Melalui Bermain, (Jakarta: Grasindo, 2008), h. 39. 
menciptakan lingkungan belajar untuk anak yang kondusif sehingga anak merasa nyaman dan pada saat belajar akan lebih efektif dan efisien. Apabila lingkungan belajar tidak kondusif kemungkinan proses belajaran tidak akan efektif dan mengalami hambatan.

Berdasarkan hasil wawancara, kendala yang di hadapi dalam melakukan kegiatan belajar anak yang akan direncanak didalam program pada perencanaan pembelajaran selanjutnya. Pada hakekatnya, sebelum memulai pembelajaran sentra seni guru ataupun orang tua ataupun orang tua di rumah sebaikny memahami pijakan lingkungan main dan menata media pembelajaran dengan rapi sesuai dengan tema pembelajaran. Di dalam menyiapkan media pembelajaran guru ataupun orang tua melakukannya secara bersamasama antar guru ataupun orang tua wali kelompok dan guru ataupun orang tua pendamping. Selanjutnya pelaksanaan yang di lakukan guru ataupun orang tua dalam mengelola sentra seni yaitu guru ataupun orang tua melakukan pijakan sebelum main kepada anak agar anak mengerti dan tertib pada saat main.

Di dalam pelaksanaan pembelajaran guru ataupun orang tua mengatur posisi duduk anak sesuai dengan permainan yang dilakukan anak baik di kursi atau di lantai. Media yang dilakukan adalah disesuaikan dengan tema yang dilakukan/direncanakan. Kemudian guru ataupun orang tua menjelaskan dan menyampaikan materi pembelajaran dengan jelas kepada anak karena guru ataupun orang tua menguasai materi sesuai tema pembelajaran. Secara rinci akan penulis uraikan dari perencanaan, pelaksanaan, dan evaluasi pembelajaran sentra seni.

\section{d. Kreativitas Anak Usia Dini}

Tahap selanjutnya, pada perencanaan pembelajaran sentra seni dalam pengembangan kreativitas anak adalah menyusun rencana kerja harian (RKM) bagi tenaga pendidik yang berfungsi sebagai pedoman guru ataupun orang tua dalam melakukan pembelajaran disentra. Rencana kerja harian dibuat setiap hari oleh guru ataupun orang tua kelas yang berwenang. Rencana Kerja Harian yang telah disusun, dalam RKH telah memuat beberapa aspek yang menjadi persyaratan 
sebagai perangkat pembelajaran yaitu aspek-aspek yang akan dikembangkan yang merupakan tujuan dari pembelajaran, tema, sub tema, tanggal pelaksanaan, jenis sentra, pijakan-pijakan yang harus dimiliki sistem sentra, jenis kegiatan yang dilakukan, bahan dan alat, serta metode penilaian.

Kemudian, untuk mengembangkan kreativitas anak dalam sentra seni seperti dapat menciptakan hasil karya melalui berbagai kegiatan pembelajaran yang dilakukan. Dengan demikian, maka seorang guru ataupun orang tua harus dapat mengelola sentra seni agar menciptakan lingkungan belajar kondusif sehingga anak merasa nyaman dan pada saat proses pembelajaran akan lebih efektif dan efisien. Apabila lingkungan belajar tidak kondusif kemungkinan proses pembelajaran tidak akan efektif dan mengalami hambatan. Dengan demikian, maka kreatifitas anak otomatis mengalami hambatan serta proses pembelajaran dianggap tidak efektif dan efisien sebagaimana yang diharapkan di dalam tujuan pembelajaran sentra seni untuk meningkaan kreativitas anak usia dini.

\section{PENUTUP}

Berdasarkan uaraian tentang "Pembelajaran Melalui Sentra Seni dalam Pengembangan Kreativitas Anak Usia Dini", dapat di tarik kesimpulan yakni: perencanaan, pelaksanaan dan evaluasi. kegiatan pembelajaran di lakukan dalam beberapa pijakan yakni: pijakan lingkungan main, pijakan sebelum main, pijakan selama main, pijakan setelah main dan beres-beres. Evaluasi yang di lakukan guru ataupun orang tua di lakukan melalui pengamatan langsung, potofolio, dan unjuk kerja. Faktor-faktor penghambat pada pengembangan kreativitas melalui pembelajaran sentra seni adalah guru ataupun orang tua belum memahami sepenuhnya tentang pengembangan kreativitas anak melalui pembelajaran sentra seni. Selain itu juga, kesulitan guru ataupun orang tua dalam menyusun kegiatan pembelajaran, terbatasnya media pembelajaran sentra seni dalam pengembangan kreativitas anak. bagi pendidik/guru ataupun orang tua, sebagai fasilitator, motivator dan evaluator dalam pembelajaran sentra seni dalam pengembangan kreativitas anak haruslah benar- 
benar memahami prosedur kerja yang benar dalam menerapkan program pembelajarn sentra seni ini.

Selain itu, karena pembelajaran sentra seni dalam pengembangan kreativitas anak ini sangat berhubungan dengan pemahaman guru ataupun orang tua tentang tahapan dan tugas perkembangan anak, pendekatan yang berpusat kepada anak implementasi pengembangan kreativitas dalam kegiatan sentra seni, maka guru ataupun orang tua perlu menyediakan waktu dan APE yang cukup bagi anak untuk berekplorasi dalam rangka pengembangan kreativitas anak. Mengembangkan kemampuan keterampilan anak dengan membiasakan anak untuk dapat membuat hasil karya sesuai dengan ide-idenya. Menyediakan sarana dan prasarana yang mendukung dalam pengembangan kreativitas anak melalui pembelajaran sentra seni.

\section{Daftar Pustaka}

Abdul Majid Khon. Hadis Tarbawi, Jakarta: Kencana Prenada Media Group, 2012.

Armstrong Thomas. On Their On Way Discovering And Encouraging Your Child Multiple Intelligence, America: Educational Leadership, 2004.

B Uno Hamzah. Perencanaan Pembelajaran, Jakarta: Bumi Aksara, 2011.

Depag RI. 2004. Al-qur'an dan Terjemahannya, Proyek Pengadaan Kitab Suci Al-qur'an, Jakarta.

Departemen Pendidikan Nasional Direktorat Jenderal Pendidikan Tinggi Direktorat Pembinaan Pendidikan Tenaga Kependidikan Dan Ketenagaan Perguru ataupun orang tua an Tinggi, Pembembangan Kreativitas Anak Usia Dini, Jakarta, 2005.

Eli Harnida. Model Pembelajaran Beyond Center And Circle Time(BCCT)

Pada Taman Kanak-Kanak Untuk Mengembangkan Kreativitas Anak, Pustaka Program Pasca Sarjana IAIN STS Jambi. 
Hasil Observasi awal, Tanggal 12 Desember 2013.

Imas Kurniasih. Pendidikan Anak Usia Dini, Jakarta: Edukasia, 2009.

Iskandar. Metodologi Penelitian Pendidikan dan Sosial Kuantitaif dan Kualitatif, Jakarta: Gaung Persada, 2008.

Koni Satria dan Hamzah B Uno. Assesment Pembelajaran, Jakarta: Bumi Aksara, 2012.

Luluk Asmawati dkk. Pengelolaan Kegiatan Pengembangan Anak Usia Dini, Jakarta: Universitas Terbuka, 2010.

Martini Jamaris. Perkembangan dan Pengembangan Anak Usia Taman Kanak-Kanak, Jakarta: Remaja Rosdakarya, 2006.

Neni Arriyani. Panduan Pendidikan Sentra Untuk PAUD, Jakarta: Sekolah Al-Falah, 2006.

Noorlaila Iva. Panduan Lengkap Mengajar PAUD, Jogjakarta: Pinus Book Publisher, 2010.

Sugiyono. Memahami Penelitian Kualitatif, Bandung: Alfabeta, 2007.

Suyadi. Permainan Edukatif yang Mencerdaskan: The Power of Smart Games For Children, Yogyakarta: Power Books, 2009.

Utami Munandar. Pengembangan Kreativitas Anak Berbakat, Jakarta: PT Indeks, 2009.

www.wikipedia.org/Penelitian kualitatif. Tanggal 15 Januari 2014.

Yuliani S Nuraini. Konsep Dasar Pendidikan Anak Usia Dini, Jakarta: PT Indeks, 2009. 